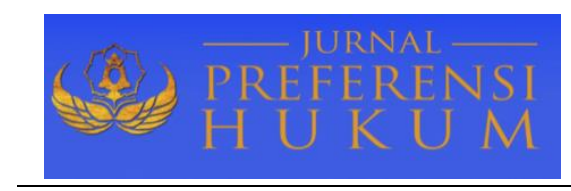

Jurnal Preferensi Hukum | ISSN: XXXX | E-ISSN: XXXX

Vol. 1, No. 2 - September 2020, Hal. 47-50| Available Online at https://www.ejournal.warmadewa.ac.id/index.php/juprehum

DOI: http://doi.org/10.22225/jph.v1i2.2341.47-50

\title{
PERLINDUNGAN HUKUM TERHADAP ANAK DALAM TERJADINYA PERCERAIAN
}

\author{
Gede Andi Wiradharma, I Nyoman Putu Budiartha, I Ketut Sukadana \\ Fakultas Ilmu Hukum Universitas Warmadewa, Denpasar - Bali, Indonesia
}

\begin{abstract}
Abstrak
Perkawinan merupakan sebuah hal yang menyatukan dua individu menjadi satu melalui sebuah upacara secara agama dan hukum. Setelah upacara pernikahan berlangung maka kedua individu tersebut adalah sebuah pasangan suami istri. Dalam menjalani perkawinan, banyak hal yang harus dilalui sehingga pasangan suami istri tersebut akan memiliki perbedaan pendapat. Perbedaan pendapat kadang membuat pasangan suami istri mengalami pertentangan yang biasanya akan menimbulkan sebuah perkelahian yang sering berujung dengan perceraian. Penelitian ini dilakukan dengan tujuan mendeskripsikan bagaimana pengaturan tentang hak asuh anak menurut hukum di Indonesia dan bagaimana perlindungan hukum terhadap hak-hak anak akibat perceraian. Penelitian ini didesain dengan menggunakan metode penelitian hukum normatif. Hasil penelitian ini menunjukkan bahwa pengaturan tentang hak asuh anak menurut hukum di Indonesia diatur dalam UndangUndang Nomor 35 Tahun 2014 tentang Perlindungan Anak dan juga disebutkan hak dan kewajiban anak. Dalam Undang-Undang ini perlindungan anak lebih diutamakan. Selain itu perlindungan hukum terhadap hak-hak anak akibat perceraian juga dijamin dimana anak tetap berhak mendapatkan hak dari orang tuanya seperti mendapatkan pendidikan, tempat tinggal dan kehidupan yang layak, merasakan keamanan, dan mendapatkan jaminan kesehatan.
\end{abstract}

Kata Kunci: Anak; Perceraian; Perkawinan

\begin{abstract}
Marriage is a thing that unites two individuals into one through a religious and legal ceremony. After the wedding ceremony takes place, the two individuals are married-couple. In undergoing marriage, a lot of things must be passed, so the husband and wife will have differences of opinion. The differences of opinion sometimes cause husband and wife to experience conflict which will usually lead to a fight that often ends to divorce. This research was conducted with the aim of describing how the regulation of child custody rights according to the law in Indonesia and how the legal protection of children's rights due to divorce. This research was designed using a normative legal research method. The results of this study showed that the regulation of child custody according to the law in Indonesia is regulated in Law Number 35 of 2014 concerning Child Protection and also mentions children's rights and obligations. In this law, child protection takes precedence. In addition, legal protection for children's rights due to divorce is also guaranteed where children are still entitled to receive rights from their parents such as getting an education, a decent place to live, feel secure, and get health insurance.
\end{abstract}

Keywords: Children; Divorce; Marriage

\section{PENDAHULUAN}

Perkawinan merupakan sebuah proses bersatunya dua individu melalui upacara agama maupun hukum. Perkawinan umumnya bertujuan untuk membangun sebuah keluarga, memiliki keturunan, dan hidup bahagia (Puspani \& Herdiyanto, 2016; Suardiman, 1998). Namun dalam sebuah perkawinan akan melalui banyak rintangan seperti perbedaan pendapat, penyusuaian sifat dan banyak hal yang dapat terjadi sehingga dapat menimbulkan sebuah ketidakharmonisan keluarga hingga pertengkaran, bahkan beberapa pasangan sampai memutuskan untuk bercerai (Afriadi, Juhaepa, \& Sarmadan, 2020; Dewi \& Basti, 2008; Harjanti, Amin, Ali, \& Kasim, 2017; Rossalia \& Priadi, 2018).

Perceraian adalah sebuah hal yang seharusnya dihindari dalam sebuah perkawinan karena sebuah perceraian dapat merugikan banyak pihak, seperti merusak nama keluarga, menimbulkan luka seorang anak. Perceraian merupakan proses putusnya suatu hubungan perkawinan melalui proses 
hukum dan agama karena tuntutan salah satu pihak. Sebuah proses perceraian harus diputuskan oleh hakim karena telah diatur dalam undang-undang bahwa sebuah proses perceraian tidak dapat diputuskan antara pasangan suami istri saja karena harus diputuskan secara sah oleh pengadilan dan harus berdasarkan atas alasan-alasan yang jelas. Dalam sebuah perceraian, banyak hal yang harus dilalui seperti keputusan pembagian harta, mengenai hak asuh anak dan beberapa hal lainnya yang harus diresmikan (Fahriyanti, 2019; Zuhrah, 2018).

Anak merupakan generasi penerus yang akan melanjutkan orang tua sehingga seorang anak harus dididik dengan baik dan benar agar anak tersebut bisa menjadi seseorang yang berguna di kemudian hari dan dapat bertaqwa kepada Tuhan dan juga dapat meneruskan cita-cita yang berdasarkan pancasila. Sebuah perceraian sering terjadi karena adanya perbedaan pendapat, perselisihan, timbulnya sebuah masalah dan ketidak harmonisan suatu hubungan keluarga. Perceraian adalah keputusan yang diambil ketika beberapa usaha telah dilakukan namun tidak menemukan penyelesaian untuk menyatukan dan memperbaiki perkawinan.

Salah satu hal yang harus diperhatikan ketika terjadinya sebuah perceraian adalah tentang hakhak yang harus didapatkan oleh seorang anak akibat terjadinya perceraian tersebut. Hak-hak yang harus didapatkan oleh seorang anak meskipun orang tuanya sudah bercerai adalah hak untuk mendapatkan kehidupan yang layak, hak mendapatkan pendidikan, hak untuk mendapatkan perlindungan, hak untuk berkembang, hak untuk mendapatkan fasilitas kesehatan dan hak-hak lainnya yang harus didapatkan oleh seorang anak (Fakhria, 2019; Yusuf, 2014).

Anak adalah pihak yang paling merasakan dampak akibat terjadinya perceraian dan sangat sering menjadi korban. Oleh karena itu, anak perlu mendapatkan perlindungan demi kelangsungan hidup dan masa depannya. Hak perlindungan tersebut sesuai dengan undang-undang nomor 35 tahun 2014 mengenai perlindungan anak.

Berdasarkan dari uraian latar belakang di atas, penelitian ini bertujuan untuk menguraikan bagaimana pengaturan tentang hak asuk anak menurut hukum di Indonesia dan bagaimana perlindungan hukum terhadap hak-hak anak akibat perceraian.

\section{METODE PENELITIAN}

Penelitian ini didesain dengan menggunakan metode penelitian hukum normatif dan pendekatan masalah konseptual. Adapun sumber bahan hukum yang digunakan ialah bersumber dari penelitian dan kepustakaan, yaitu: bahan hukum primer berupa Peraturan Perundang-Undangan yakni hukum positif Indonesia yang diambil dari undang-undang RI tahun 1945, undang-undang RI nomor 4 tahun 1979 mengenai hak anak, KUH Per, UU perkawinan no 1 tahun 1974, UU no 35 tahun 2014 mengenai perubahan perlindungan anak. Selain itu, bahan hukum sekunder juga digunakan, yaitu bahan hukum yang berupa buku literature, hasil karya tulis ilmuah. Bahan hukum lain yang digunakan adalah bahan hukum tersier yang berupa kamus ensiklopedia dan kamus besar Bahasa Indonesia.

Teknik yang digunakan untuk mengumpulkan bahan hukum dalam penelitian ini ialah teknik kepustakaan dirangkum dengan cara mencari, meringkas, menyatat, dan mempelajari buku-buku ilmiah yang ada tentang pendapat para ahli. Peraturan perundang-undangan juga dipakai untuk melengkapi penelitian ini. Data yang sudah terkumpul dianalisis menggunakan metode kualitatif dan disajikan secara deskriptif.

\section{HASIL DAN PEMBAHASAN}

\section{Pengaturan tentang Hak Asuh Anak Menurut Hukum di Indonesia}

Anak merupakan seseorang yang lahir dari hasil perkawinan antara seseorang laki-laki dengan wanita, dan yang dilahirkan oleh seorang wanita walaupun tidak atas dasar perkawinan tetap disebut anak. Anak adalah asset bangsa yang merupakan generasi baru penerus cita-cita bangsa dan juga sumber daya manusia bagi pembangunan nasional. Maka dari itu, kepribadian anak sangat menentukan kehidupan masa depan bangsa yang akan datang.

Anak merupakaan subjek hukum nasional yang harus dilindungi, dibina, dibesarkan, dan dipelihara. Tanggung jawab pemerintah dan masyarakat, anak juga berhak untuk pelayanan, pengembangan di bidang kemampuan dan kehidupan sosial. Anak berhak terhadap pemeliharaan dan perlindungan sejak dalam kandungan maupun sudah dilahirkan.

Selama anak tersebut belum pernah menikah maka anak tersebut masih berada di bawah kekuasaan orang tua. Namun belum menunjukan hasil, bahwa masyarakat Indonesia bisa memenuhi 
sesuai kebutuhan dan perkembangannya. Hal ini menyebabkan kondisi dan situasi serta keterbatasan pemerintah juga masyarakat yang belum mungkin mengembangkan secara nyata peraturan UU yang sudah ada.

Dalam pengajuan permohonan perceraian dapat diajukan juga permohonan atas hak asuh anak kepada pengadilan. Salah satu pihak dapat mengajukan permohonan hak asuh anak demi kepentingan dan keberlangsungan masa depan anak. Secara umum anak berhak mendapat perlakuan yang baik, kasih sayang meskipun kedua orang tua telah bercerai, tetapi anak harus tetap mendapatkan kasih sayang. Anak juga berhak untuk tetap mendapatkan jaminan pendidikan, kehidupan yang layak, kesehatan, dan perlindungan.

Hak asuh anak menurut hukum di Indonesia menyebutkan Undang-Undang Nomor 35 Tahun 2014 tentang Perlindungan Anak juga disebutkan hak dan kewajiban anak. Dalam Undang- undang ini perlindungan anak lebih diutamakan, dimana hal ini tetap harus dilakukan meskipun diantara ibu atau ayahnya yang bersengketa salah satunya berkeyakinan di luar Islam, atau diantara mereka berlainan bangsa, namun dalam memutuskan terhadap pilihan anak tersebut harus melihat keadaan anak tersebut.

\section{Perlindungan Hukum terhadap Hak-Hak Anak Akibat Perceraian}

Perceraian adalah putusnya hubungan pernikahan yang diakibatkan oleh sebuah ketidakcocokan, perbedaan pendapat yang membuat sebuah perkawinan tidak dapat dipertahankan. Perkawinan yang umumnya terdiri dari dua orang yang tinggal dan hidup bersama yang memiliki latar belakang, keinginan, nafsu, kebutuhan, serta nilai sosial yang bisa saja berbeda satu dengan yang lainnnya. Hal ini mengakibatkan munculnya ketegangan dan ketidakbahagiaan yang dirasakan semua anggota keluarga yang dapat menimbulkan terjadinya perceraian.

Perlindungan anak dibedakan menjadi dua yaitu, bersifat yuridis dan non yuridis. Perlindungan yuridis terdapat aturan hukum yang berakibat langsung bagi anak. Sedangkan perlindungan non yuridis menyangkut perlindungan dalam beberapa bidang, yaitu: 1) dalam bidang sosial yang ada hubungannya dengan perlindungan anak untuk bermasyarakat atau bersosial dan lingkungan yang kondusif untuk tumbuh kembang anak juga pengadaan kondisi sosial. Seorang anak mempunyai hak untuk dapat tempat layak untuk hidup dan berkembang. 2) Dalam bidang kesehatan yang ada hubungannya dengan perlindungan juga kesehatan anak baik jasmani dan juga rohani serta melakukan tindakan meningkatkan gizi dan kesehatan anak. Pemerintah seharusnya bisa memberikan jalan yang mudah agar anak bisa mendapat jaminan kesehatan, memberikan fasilitas kesehatan gratis agar dilakukan untuk baiknya tumbuh kembang anak. 3) Dalam bidang pendidikan menyangkut hak anak agar dapat meningkatkan kualitas pendidikan dengan banyak program bantuan serta fasilitas pendidikan canggih dan lengkap, guna meningkatkan perkembangan anak.

\section{SIMPULAN DAN SARAN}

\section{Simpulan}

Berdasarkan hasil dan pembahasan di atas, ada beberapa simpulan yang dapat dibuat, yaitu: pertama, hak asuh anak menurut hukum di Indonesia menyebutkan Undang-Undang Nomor 35 Tahun 2014 tentang Perlindungan Anak juga disebutkan hak dan kewajiban anak. Dalam Undang-Undang ini perlindungan anak lebih diutamakan, dimana hal ini tetap harus dilakukan meskipun diantara ibu atau ayahnya yang bersengketa salah satunya berkeyakinan di luar Islam, atau diantara mereka berlainan bangsa, namun dalam memutuskan terhadap pilihan anak tersebut harus melihat keadaan anak tersebut. Kedua, anak tetap berhak mendapatkan hak dari orang tuanya seperti mendapatkan pendidikan, tempat tinggal dan kehidupan yang layak, merasakan keamanan, dan mendapatkan jaminan kesehatan meskipun keduanya telah melakukan perceraian.

\section{Saran}

Ada juga beberapa saran yang perlu disampaikan kepada beberapa pihak berdasarkan hasil penelitian ini, yaitu: pertama, bagi anak muda yang hendak membentuk keluarga sebaiknya sebelum melangsungkan pernikahan ada baiknya untuk mempersiapkan mental dan mengetahui kemungkinankemungkinan yang akan terjadi ketika sudah menjalani kehidupan berumah tangga, sehingga dalam menjalani kehidupan berumahtangga bisa lebih bijak dalam mengambil keputusan juga lebih bisa mengkondisikan diri dalam suatu permasalahan. Kedua, bagi orang tua juga perlu memperhatikan 
hak-hak anak yang menjadi kewajiban orang tua seperti menjamin kesehatan anak, menjamin pendidikan anak dan beberapa hal lainnya yang menjadi kewajiban orang tua terhadap anak.

\section{DAFTAR PUSTAKA}

Afriadi, A. I., Juhaepa, \& Sarmadan. (2020). Catatan Keluarga Broken Home dan Dampaknya terhadap Mental Anak di Kabupaten Kolaka Timor. Journal of Social Welfare, 1(1), 31-41.

Dewi, E. M. P., \& Basti. (2008). Konflik Perkawinan dan Model Penyelesaian Konflik pada Pasangan Suami Istri. Jurnal Ilmiah Psikologi Gunadarma, 2(1), 42-51.

Fahriyanti, N. (2019). Gugat Cerai: Membebaskan Prempuan dari Penderitaan? Qawwam, 13(2), 101122.

Fakhria, S. (2019). Cerai Gugat dan Implikasinya terhadap Hak-Hak Finansial Perempuan. Legitima: Jurnal Hukum Keluarga Islam, 1(1), 96-119.

Harjanti, S., Amin, M., Ali, B., \& Kasim, A. (2017). Konflik Perkawinan di Kabupaten Sambas. Jurnal Diskursus Islam, 5(2), 161-183.

Puspani, N. L. K. D., \& Herdiyanto, Y. K. (2016). Proses Penerimaan Dukungan Sosial Orangtua pada Laki-laki dalam Perkawinan Nyentana. Jurnal Psikologi Udayana, 3(3), 79-91.

Rossalia, N., \& Priadi, M. A. G. (2018). Conflict Management Style pada Pasangan Suami Istri yang Tinggal bersama Mertua. Jurnal Ilmiah Psikologi MANASA, 7(1), 35-50.

Suardiman. (1998). Kehidupan Perkawinan Bahagia: Dampak Positif untuk Keseimbangan Mental Anak Kini dan Nanti. Buletin Psikologi, 6(2), 40-49.

Yusuf, M. (2014). Dampak Perceraian Orang Tua terhadap Anak. Jurnal Al-Bayan, 20(29), 33-44.

Zuhrah, F. (2018). Perempuan Menggugat: Telaah Perceraian Wanita Muslimah Berkarir di Kota Medan. MIQOT: Jurnal Ilmu-Ilmu Keislaman, 42(2), 319-334. 